\title{
PENGARUH KUALITAS LAYANAN TERHADAP KEPUASAN DAN KOMITMEN NASABAH TABUNGAN BANK PEMBANGUNAN DAERAH (BPD) CABANG UTAMA KENDARI
}

\author{
Hayat Yusuf \\ Email : hayatyusufabadi77@gmail.com
}

\begin{abstract}
Abstrak: Penelitian ini bertujuan untuk menguji dan menganalisis : (1) Pengaruh kualitas layanan terhadap kepuasan nasabah pada BPD Sultra Cabang Utama; (2) Pengaruh kualitas layanan terhadap komitmen nasabah pada BPD Sultra Cabang Utama; (3) Pengaruh kepuasan terhadap komitmen nasabah pada BPD Sultra Cabang Utama. Penelitian ini menggunakan sampel 121 orang nasabah tabungan BPD Sultra Cabang Utama. Metode analisa data yang digunakan adalah statistik deskriptif dan statistik inferensial dangan alat analisis yang digunakan adalah Struktural Equation Modelling (SEM). Dengan menggunakan paket program AMOS versi. 16.0. Hasil penelitian menyatakan bahwa ada pengaruh dan signifikan antar veriabel kualitas layanan, kepuasan dan komitmen nasabah BPD Cabang Kendari.
\end{abstract}

Kata Kunci: Kulitas Layanan, Kepuasan dan Komitmen Nasabah

\section{PENDAHULUAN}

Bisnis perbankan di Indonesia diera tahun 1960-an dan 1970-an merupakan bisnis yang belum terkenal. Bank hanya bisnis yang asing. Yang hanya diketahui oleh orang-orang tertentu. Ketika itu bank tidak pernah mencari nasabah, tapi nasabahlah yang datang mencari bank. Kemudian pada tahun 1980-an dan 1990-an kesan dunia perbankan menjadi terbalik, karena diera ini perbankan justru mulai aktif mencari nasabah. Bisnis perbankan semakin kompleks dengan keberadaan bank-bank asing yang turut memperebutkan pasar yang sama semakin memperketat persaingan. Karena bank asing tersebut memiliki kelebihan seperti brand nama yang sudah mendunia, jaringan yang mengglobal serta produk yang ditawarkan lebih inovatif. Selain itu, munculnya lembaga-lembaga keuangan non bank yang beroperasi secara lebih khusus seperti perusahaan asuransi, pegadaian, usaha leasing dan perusahaan sekuritas yang semakin banyak, menambah daftar pesaing dalam meraih pangsa pasar yang lebih luas.

Namun di tahun 1997 hingga tahun 2000 merupakan kehancuran dunia perbankan Indonesia dimana puluhan bank dilikuidasi dan yang lainnya dimerger akibat kerugian bank yang terus menerus baik milik pemerintah maupun swasta. Kepercayaan nasabah terhadap perbankan nasional menurun drastis,

Hayat Yusuf, adalah Dosen Fakultas Ekonomi Universitas Halo Uleo Kendari 
mengakibatkan banyaknya nasabah menarik dananya pada bank-bank tersebut. Peristiwa ini menunjukkan bahwa mengelola bank harus dilakukan secara professional, sehingga dapat memperoleh keuntungan terus menerus, seperti tujuan utama bank didirikan.

Ada beberapa masalah yang dihadapi dunia perbankan di dalam menghadapi perkembangannya : (1) Bank harus mengejar pertumbuhan dan perluasan. Perbankan tidak hanya merupakan industri jasa yang masih labor intensive, akan tetapi semakin menjadi knowledge intensive. Sehingga bank harus menyempurnakan kegiatan operasional dan manajemennya secara kualitatif maupun kuantitatif antara staf dan personil, (2) Bank dituntut untuk memberikan pelayanan yang cepat dan akurat. Mengingat bahwa bank hampir selalu terlibat dalam transaksi bisnis, maka kualitas pelayanan bank merupakan faktor yang ikut menentukan, (3) Perubahan teknologi. Bidang teknologi menjalani perubahan yang cepat, khususnya dibidang computer dan aplikasinya pada dunia perbankan,(4) Perubahan struktur dana-dana. Dewasa ini berbagai faktor telah mempengaruhi komposisi dan dana-dana bank. Di Indonesia. berkembangnya berbagai lembaga keuangan, pertumbuhan money dan capital market telah menggeser sumbersumber dana Bank sehingga mempengaruhi struktur biaya dananya, (5) Persaingan. Kehadiran lembaga-lembaga keuangan, perkembangan yang terjadi pada masingmasing kelompok bank, baik bank pemerintah, bank swasta nasional maupun bank asing, semakin mewarnai persaingan dilingkungan perbankan di Indonesia. Dilain pihak Pemerintah berusaha menciptakan suatu bentuk persaingan yang sehat guna mendorong kemajuan dunia perbankan.

Dilihat dari sudut pandang pelanggan, situasi persaingan ini sebenarnya akan memberikan suatu keuntungan tersendiri. Dengan tingginya tingkat persaingan bank berarti akan memberikan keleluasaan kepada pelanggan untuk menentukan pilihan, sehingga pihak bank harus bersedia memberikan pelayanan yang paling sesuai dengan keinginan-keinginan pelanggannya. Apalagi dewasa ini tuntutan pelanggan juga semakin beragam, dimana dengan didukung oleh tingkat pendidikan yang semakin tinggi dan kemudahan memperoleh informasi, maka tuntutan dan fleksibilitas mereka pun semakin tinggi. Kecepatan, keamanan, kemudahan dan keramahan pelayanan semakin dipersyaratkan pelanggan dalam menentukan pilihan layanan perbankan disamping tingkat harga dan bunga dan biaya jasa yang memadai. Sehingga bank-bank yang saling bersaing akan berupaya meningkatkan kualitas layanannya dalam rangka memenuhi tuntutan nasabah. Saat ini kompetisi persaingan diantara bank-bank di wilayah Kota Kendari sudah cukup tinggi. Dengan adanya 21 bank yang beroperasi memperebutkan pangsa pasar yang sama, maka usaha menjaring dan mempertahankan nasabah semakin ketat. Bank harus jeli melihat dan memanfaatkan celah-celah peluang yang ada. Berbagai pelayanan dan kemudahan bertransaksi ditawarkan. Selalu memberikan Service Excellence (layanan prima) menjadi slogan dan tujuan mereka dalam melayani demi memuaskan nasabahnya.

Walaupun demikian, fasilitas fisik bukan satu-satunya bentuk layanan diantara banyaknya layanan jasa yang dapat ditawarkan oleh bank. Sebab seperti telah diuraikan diatas bahwa layanan bank merupakan layanan jasa profesional. Masyarakat atau calon nasabah akan terlebih dahulu melihat apa yang menjadi kebutuhan dan keinginan mereka sebelum melakukan pembelian. Penciptaan 
pelayanan yang sempurna dapat dirusak oleh suatu penyampaian pelayanan atau cara penjualan yang buruk. Dengan adanya publikasi negatif terkait pelayanan yang diberikan, BPD Sultra Cabang Utama berupaya berbenah demi meningkatkan pelayanan mereka, sehingga dapat meningkatkan kepuasan, komitmen nasabah yang pada akhirnya meningkatkan relationship intention nasabah terhadap bank.

Faktor lain yang mempengaruhi komitmen adalah kepuasan. Kepuasan adalah evaluasi pelanggan terhadap produk atau jasa yang didasarkan pada apakah produk atau jasa dapat memenuhi kebutuhan dan harapan (Zeithaml and Bitner, 2003:86). Tingkat kepuasan yang tinggi memperkuat keinginan pelanggan untuk memiliki komitmen terhadap perusahaan. Kepuasan pelanggan yang terus-menerus akan mengarah pada pembinaan hubungan yang baik. Sebagai hasil dari perasaan yang baik dan benar-benar terpuaskan, besar kemungkinan pelanggan akan melakukan pembelian-pembelian yang lain sehingga akan tercipta hubungan yang lebih kuat dalam jangka panjang.

Hennig-Thurau et al. (2002) dalam penelitiannya menemukan bahwa kepuasan secara signifikan mempengaruhi komitmen. Dengan adanya tingkat kepuasan yang tinggi pelanggan akan mendapat kekuatan kembali untuk melakukan pembelian sehingga akan menciptakan komitmen yang menunjukkan adanya ikatan emosional. Boonajsevee (2005) juga menemukan bahwa terdapat korelasi yang positif antara kepuasan dan komitmen. Nasabah yang menerima pelayanan yang memuaskan akan komit pada bank tertentu dan masuk ke dalam relationship. Nasabah kurang suka mengembangkan relationship yang baru dengan bank lain apabila sudah memiliki kedekatan emosional yang kuat dengan suatu bank tertentu. Sementara itu, Garbarino and Johnson (1999) menemukan bahwa kepuasan pelanggan tidak berpengaruh signifikan terhadap komitmen. Berdasarkan pada uraian diatas, maka penelitian ini mencoba mengkaji pengaruh kualitas layanan terhadap kepuasan, dan komitmen pelangan.

\section{TINJAUAN PUSTAKA}

\section{Konsep Kualitas Layanan (Service Quality)}

Kualitas layanan/jasa difokuskan pada upaya untuk memenuhi kebutuhan dan keinginan pelanggan sehingga penyedia jasa dapat memenuhi harapan pelanggan.Dengan demikian, kualitas jasa (service quality) dibangun atas adanya perbandingan dua faktor utama yaitu persepsi pelanggan atas pelayanan yang nyata mereka terima (perceived service) dengan layanan yang sesungguhnya diharapkan/diinginkan (expected service).Hal tersebut sejalan dengan definisi yang dikemukakan oleh Ziethaml (1993), bahwa kualitas jasa (Service Quality) adalah tingkat perbedaan antara ekspektasi pelanggan dengan persepsi pelanggan. Perbandingan antara ekspektasi dan persepsi bisa memunculkan tiga kemungkinan yaitu persepsi lebih besar daripada eksektasi nasabah, yang berarti nasabah merasa sangat puas dengan kualitas pelayanan yang diberikan bank, persepsi lebih kecil daripada ekspektasi nasabah yang berarti harapan nasabah terhadap kualitas pelayanan bank tidak tercapai. Jika persepsi sama dengan harapan nasabah terhadap kualitas jasa pelayanan bank dapat dikatakan nasabah puas (Sugiarto, 1999 : 66). 
Bowers et al (1994) mengemukakan dimensi dari kualitas pelayanan, meliputi Tangibles, Reliability, Responsiveness, Assurance, dan Emphaty. Tangibles menunjukkan fasilitas fisik yang nampak, termasuk penampilan produk.Reliability menunjukkan kesesuaian kualitas produk sesuai dengan yang dijanjikan.Responsiveness merujuk pada kemauan produsen dalam menanggapi keluhan konsumen.Assurance menunjukkan adanya jaminan yang diberikan produsen terhadap produk yang dibeli.Sedangkan Empathy menunjukkan perhatian produsen untuk dapat memposisikan diri sebagai konsumen.

Sedangkan Parasuraman, et al., (1988) merangkum 10 dimensi service quality yang diajukan pada tahun 1985 (reliability, responsiveness, competence, access, courtesy, communication, credibility, security, understanding/knowing the customer, tangibles) menjadi lima dimensi. Kelima dimensi kualitas pelayanan tersebut adalah :

1. Tangibles, meliputi fasilitas fisik, perlengkapan, dan penampilan personil.

2. Reliability, meliputi kemampuan melakukan layanan atau jasa yang diharapkan secara meyakinkan, akurat dan konsisten.

3. Responsiveness, meliputi kemauan memberikan layanan cepat dan membantu pelangggan.

4. Assurance, meliputi pengetahuan, sopan santun, dan kemampuan karyawan menyampikan kepastian dan kepercayaan.

5. Empathy, meliputi perhatian individual pada pelanggan, kemudahan dalam melakukan hubungan, komunikasi yang baik, dan memahami kebutuhan para pelanggan.

Dalam penelitian ini dimensi kualitas layanan yang akan digunakan akan mengadopsi kelima dimensi kualitas layanan yang dikemukakan oleh Parasuraman, et al., (1988) tersebut.

\section{Kepuasan Pelanggan}

Pada awalnya teori tentang kepuasan pelanggan mengkonsepkan standar yang sederhana, yaitu harapan bagaimana jasa akan melakukan fungsinya. Tetapi dari hasil penelitian yang pernah dilakukan Woodrulff and Gardial (1996) dalam Astuti (2001) membuktikan bahwa standar perbandingan yang digunakan bermacam-macam dan bahkan bervariasi sepanjang proses konsumsi. Standar lain selain harapan yang digunakan sebagai pembanding adalah produk ideal, produk pesaing, katagori produk yang lain, janji dari para pemasar (yang dibuat melalui komunikasi pemasaran) dan norma industri (Woodrulff and Gardial : ibid).

Selama dua dekade yang lalu, manajemen kepuasan pelanggan telah muncul sebagai suatu strategis yang harus dijalankan oleh sebahagian besar perusahaan. Mencapai peringkat kepuasan pelanggan yang lebih tinggi telah dijadikan tujuan perusahaan. Selanjutnya pada dekade 1990-an orang mulai menyadari bahwa penentu kepuasan pelanggan merupakan alat strategis untuk mempertahankan pelanggan yang secara langsung mempengaruhi profit (Mittal dan Kamakura, 2001). Dorongan untuk mempertahankan pelanggan ini didasari kenyataan bahwa mempertahankan pelanggan lebih murah daripada mendapatkan pelanggan baru, juga lebih murah daripada mempertahakan pelanggan yang baru diperoleh (Mittal dan Kamakura, 2001). 
Menurut Kotler (2005), kepuasan adalah perasaan seseorang menyangkut kenyamanan atau kekecewaan sebagai akibat dari perbandingan antara kinerja (atau outcome) produk yang dipersepsikan dalam kaitannya dengan harapannya. Jadi apakah pembeli puas setelah membeli adalah tergantung pada kinerja yang ditawarkan dalam hubungannya dengan terpenuhi-tidaknya harapan pembeli. Dengan demikian, kepuasan atau ketidakpuasan pelanggan merupakan perbedaan antara harapan (expectations) dan kinerja yang dirasakan (Perceived performance), yaitu penilaian antara harapan pembelian dengan kinerja yang dirasakan pada purna pembelian dari produk atau jasa yang bersangkutan (Rodhiah, 1997). Jika kinerja tidak sesuai dengan harapan, pelanggan akan tidak puas. Jika kinerja sesuai dengan yang diharapkan, maka pelanggan akan puas. Jika kinerja melebihi yang diharapkan maka pelanggan akan sangat puas.

Kepuasan pelanggan dapat diartikan sebagai rasa senang atau tidak senang yang dirasakan oleh konsumen ketika mengevaluasi hasil konsumsinya terhadap suatu jenis produk atau jasa. Czepiel (1992) mengemukakan "because satisfaction is defined (and can be mearused) as the discrepancy between expectation and perceived reality, a firm can change its custumers satisfaction without changing its offering at all. Menurut Fornell, et al., (1996) kepuasan pelanggan secara keseluruhan mempunyai tiga anteseden, yaitu kualitas yang dirasakan, nilai yang dirasakan dan harapan pelanggan. Kualitas yang dirasakan secara langsung mempunyai efek positif terhadap kepuasan pelanggan dan secara keseluruhan akan berpengaruh negatif pada komplain pelanggan dan berpengaruh positif pada kesetiaan pelanggan.

Tjiptono (1998) menyatakan bahwa perasaan puas pelanggan timbul ketika pelanggan membandingkan persepsi mereka mengenai performance product atau service dengan harapan mereka. Kepuasan dan ketidakpuasan pelanggan adalah respon pelanggan terhadap evaluasi ketidaksesuaian (disconfirmation) yang dirasakan antara harapan sebelumnya (norma kerja lainnya) dengan kinerja aktual produk yang dirasakan setelah pemakaiannya. Terdapat dua variabel utama menentukan kepuasan pelanggan yaitu expectation dan perceived performance. Apabila expectation melebihi dari perceived performance maka pelanggan akan merasa puas, apabila terjadi sebaliknya maka pelanggan akan merasa tidak puas.

Zeithalm (1994) dalam temuannya menyebutkan bahwa, (1). Kepuasan pelanggan secara menyeluruh adalah hasil evaluasi dari pengalaman konsumsi sekarang yang berasal dari kebiasaan, keandalan dan standarisasi pelayanan, (2). Kepuasan pelanggan secara menyeluruh adalah hasil perbandingan tingkat kepuasan dari usaha yang sejenis, (3). Bahwa kepuasan secara menyeluruh diukur berdasarkan tingkat kepuasan pelanggan berdasarkan pengalaman indikator harapan secara keseluruhan, harapan yang berhubungan dengan kebiasaan dan harapannya yang berhubungan dengan jasa tersebut.

Selanjutnya Zeithalm (1994) memandang tingkat kepuasan (satisfaction) pelanggan dapat timbul disebabkan oleh adanya suatu transaksi khusus antara produsen dengan pelanggan yang merupakan kondisi psikologi yang dihasilkan ketika faktor emosi mendorong harapan (expectation) menyesuaikan (matching) dengan pengalaman mengkonsumsi sebelumnya (perception). Antara kepuasan dengan sikap terdapat perbedaan. Sikap pelanggan bersifat relatif terhadap produk 
atau proses (misal: costumer service) sedangkan kepuasan adalah relatif emosional (disconfirmation) terhadap pengalaman mengkonsumsi sebelumnya.

Sementara itu, untuk melakukan pengukuran terhadap kepuasan pelanggan, telah banyak peneliti yang memberikan alternatif pengukuran yaitu Albert Caruana (2000) dan Jamal dan Naser (2002, dimodifikasi) yang menggunakan empat item pengkuran kepuasan pelanggan yaitu:

1. Harapan terhadap kinerja produk/jasa

2. Prestasi terhadap kinerja produk/jasa

3. Ketidaksesuaian terhadap kinerja produk/jasa

4. Kepuasan terhadap kinerja produk/jasa

\section{Konsep Komitmen}

Barnes (2003:150) mendefinisikan komitmen sebagai suatu keadaan psikologis seseorang yang secara global merasa ketergantungan pada suatu hubungan.Sedangkan Kalafatis dan Miller (1998), Beaton dan Beaton (1995) dan Russbult dan Buunk (1993) meneliti pentingnya komitmen sebagai indikator dari stabilitas dan keberhasilan dalam hubungan jangka panjang dengan kon sumen.

Morgan dan Hunt (1994) mendefinisikan komitmen hubungan sebagai mitra pertukaran yang percaya bahwa hubungan yang sedang berjalan begitu penting, dan untuk menjamin usaha maksimum yang telah dilakukan untuk memeliharanya, mitra pertukaran bersepakat atas dasar kepercayaan menjaga hubungan yang telah terjalin. Dalam kaitan dengan definisi tersebut, Morgan dan Hunt (1994) menyatakan bahwa berbagai pihak yang terlibat dalam pertukaran mengidentifikasikan komitmen diantara mitra pertukaran merupakan kunci dalam meraih keluaran bernilai bagi mereka sendiri, dan mereka berusaha membangun dan memelihara atribut tidak ternilai dalam pertukaran yang mereka lakukan.

Sedangkan menurut Anderson and Weitz (1992) komitmen didefinisikan sebagai suatu keinginan dari kegiatan untuk membangun hubungan yang stabil dengan kesungguhan untuk memberi pengorbanan guna menjaga atau mempertahankan hubungan tersebut.Keinginan untuk menjaga hubungan yang stabil dan kesediaan melakukan pengorbanan untuk memperoleh keuntungan jangka panjang merupakan faktor penting untuk dibangun dalam suatu komitmen hubungan bisnis. Komitmen dalam kemitraan bisnis merupakan perwujudan dan keinginan yang kuat setiap pihak yang berkepentingan dalam menjaga dan mempertahankan hubungan penting tersebut (Moorman, Zaltman, and Despande, 1992)

Sedangkan menurut Anderson and Weitz (1992) bahwa variabel komitmen dalam suatu hubungan bisnis dapat diukur dengan indikator : keinginan mempertahankan hubungan bisnis, kemauan memelihara hubungan bisnis dan keyakinan akan kestabilan hubungan bisnis. Adapun indikator pengukuran komitmen nasabah dalam penelitian ini mengadopsi dari indikator yang dikemukakan oleh Anderson and Weitz.

\section{Kerangka Konseptual}

Berdasarkan beberapa kajian teoritis dan kajian empirik akan dibangun suatu kerangka yang bertujuan untuk melihat pengaruh kualitas layanan terhadap kepercayaan dan komitmen nasabah serta dampaknya terhadap loyalitas nasabah, 
maka dapat dikembangkan suatu kerangka konseptual. Model konseptual dalam penelitian ini dibangun dengan menggunakaan analisis Struktural Equation Modelling (SEM).

Kualitas layanan merupakan faktor penting untuk mempertahankan nasabah untuk tidak berpindah pada perusahaan lain. Bank harus berusaha sebaik mungkin untuk menciptakan dan meningkatkan loyalitas nasabahnya dengan jalan memberikan layanan yang berkualitas. Kualitas layanan yang dimaksud terdiri dari kelengkapan dan tampilan fisik layanan yang ada di bank (tangibles), proses pelayanan yang yang cepat dan akurat (reliability), cara petugas bank yang tanggap, sopan dan ramah ketika melayani nasabah (responsiveness), terjaminnya kerahasiaan data nasabah, penyelesaian komplain sesuai yang dijanjikan, serta adanya perhatian tulus yang ditunjukkan oleh petugas bank atas keluhan nasabah. Semua bentuk layanan ini dimaksudkan untuk memenuhi kebutuhan, keinginan dan harapan nasabah.

Sejalan dengan rasa percaya tersebut yang terus dipupuk bank, semakin lama akan membentuk komintmen yang kuat dari nasabahnya untuk selalu menjalin hubungan baik dengan bank. Sehingga kepuasan menjadi aspek yang penting untuk diperhatikan karena menjadi unsur yang memberikan pengaruh positif terhadap komitmen nasabah. Komitmen nasabah ditunjukkan dengan sikap atau perilaku nasabah yang terikat dengan bank. Nasabah yang komit akan terus menjalin dan membangun hubungan tidak ternilai dalam pertukaran yang mereka lakukan. Sebab nasabah merasakan manfaat yang besar dalam pertukaran tersebut, sehingga mereka akan tetap berada dalam jalinan kerjasama. Keberadaan nasabah dalam mitra pertukaran tersebut dibuktikan dengan intensitas mereka menggunakan produk dan jasa yang ditawarkan bank. Disamping itu, nasabah yang loyal akan dengan senang hati menceritakan pengalaman positif mereka terkait dengan produk dan jasa yang telah diterimanya kepada pihak lain. Dalam jangka panjang, hal ini memberi keuntungan bagi bank yakni naiknya reputasi bank.

Berdasarkan uraian diatas dan untuk memberikan arah bagi penelitian ini maka diperlukan suatu kerangka konseptual penelitian yang dapat menjelaskan pengaruh kualitas layanan, terhadap kepuasan, komitmen nasabah dan relationship intention nasabah. Adapun model kerangka konseptual dapat dilihat pada gambar 1 berikut :

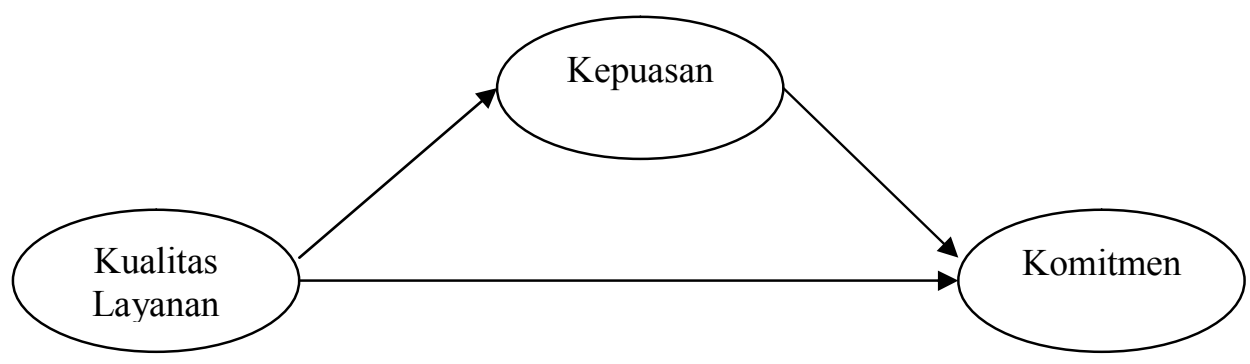

Gambar 1 : Kerangka Konseptual

\section{Hipotesis}

1. Kualitas layanan berpengaruh terhadap kepuasan nasabah BPD Cabang Utama Kendari 
2. Kualitas layanan berpengaruh terhadap komitmen nasabah BPD Cabang Utama Kendari

3. Kepuasan berpengaruh terhadap komitmen nasabah BPD Cabang Utama Kendari

\section{METODE}

\section{Rancangan Penelitian}

Berdasarkan sifat permasalahan dan tujuan yang ingin dicapai, maka penelitian ini bersifat explanatory. Penelitian yang bersifat explanatory umumnya bertujuan untuk menjelaskan kedudukan variabel-variabel yang diteliti serta hubungan dan pengaruh antara satu variabel dengan variabel yang lain (Sugiono : 2002). Penelitian ini dilakukan pada BPD Sulawesi Tenggara Cabang Utama.

\section{Populasi dan Sampel}

Populasi menurut Arikunto (2000:109) adalah jumlah keseluruhan subyek penelitian. Sedangkan sampel merupakan sebagian dari populasi yang karakteristiknya hendak diselidiki dan dianggap bisa mewakili keseluruhan populasi yang berjumlah 6.195 nasabah. (PNS tidak akan menjadi subyek dalam penelitian ini). Sehingga sampel dalam penelitian ini adalah 121 nasabah dengan menggunakan rumus slovin (presisi 9\%).

\section{Jenis dan Sumber Data}

Data yang digunakan dalam penelitian ini yakni : (1) Data primer yaitu data yang diperoleh secara langsung dari responden atau yang menjadi sampel dari penelitian ini. (2) Data sekunder yaitu data yang diperoleh dari data dokumendokumen penunjang seperti gambaran umum perusahaan, jumlah nasabah, jurnaljurnal dan buku yang berkaitan dengan penelitian ini yang diperoleh dari sumber terkait.

\section{Metode Pengumpulan Data}

Metode pengumpulan data yang digunakan dalam penelitian ini melalui cara: Kuisioner, Interview (wawancara), dan Dokumentasi.

\section{Skala Pengukuran Data}

Skala Likert digunakan dalam pengukuran variabel bebas dan terikat.Skala likert ini termasuk data interval yang digunakan untuk mengukur sikap,pendapat dan persepsi seseorang atau sekelompok menggunakan lima kategori derajat kesetujuan (likert skala) yakni :mulai dari skor 1 sampai dengan skor 5.

\section{Teknik Analisa Data}

Untuk menganalisa data, pencapain tujuan penelitian serta pengujian hipotesis yang diajukan, maka data yang diperoleh selanjutnya akan diolah sesuai dengan kebutuhan analisis. Teknik yang digunakan adalah teknik analisis statistik deskriptif dan statistik inferensial. 
Analisis statistik deskriptif ditujukan untuk memperoleh gambaran tentang kondisi relationship intention nasabah pada BPD Sultra Cabang Utama dan untuk mengidentifikasi karakteristik masing-masing variabel dalam bentuk frekuensi dan persentase.

Sedangkan analisis statistik dengan menggunakan statistik inferensial adalah teknik statistik yang digunakan untuk menganalisis data sampel dan hasilnya diberlakukan untuk populasi. Statistik ini akan cocok digunakan bila sampel diambil dari populasi yang jelas, dan teknik pengambilan sampel dari populasi itu dilakukan secara random (Sugiyono, 2001). Analisis yang digunakan untuk menjawab hipotesis dalam penelitian ini menggunakan Model Persamaan Struktur (Structural Equation Model atau SEM) dengan menggunakan paket program AMOS 16,0 dan program SPSS Versi 18,0.

\section{PEMBAHASAN}

\section{Analisis dan Hasil Penelitian.}

Teknik analisis yang di gunakan dalam penelitian ini adalah model persamaan struktural (structural equation modeling) dan proses analisisnya menggunakan program aplikasi AMOS (analysis of moment structure) versi 16.00 dari Arbuckle (1994-2003). Model persamaan struktural terdiri dari model pengukuran (measurement models) dan model struktural (structure model). Model pengukuran ditujukan untuk mengkonfirmasi indikator-indikator yang digunakan dalam membentuk suatu faktor (konstruk variabel laten), apakah indikatorindikator yang digunakan dalam penelitian ini dapat membentuk atau tidak dapat membentuk variabel laten yang dibentuknya.

Pengujian terhadap model struktural yang dikembangkan dalam penelitian, terdapat beberapa asumsi-asumsi yang harus dipenuhi. Asumsi tersebut harus diuji terlebih dahulu, yang terdiri atas : ukuran sampel, validitas dan realibilitas, normalitas, dan outliers. Setelah dilihat berdasarkan hasil pengujian data semua asumsi-asumsi yang tersebut diatas memenuhi syarat-syarat dan ketentuan dalam hal ini tidak melebihi batas Cut Of Value. Maka data dianggap layak untuk dilakukan pengujian model.

\section{Ukuran Sampel}

Menurut Ferdinand (2002:51) ukuran sampel yang harus dipenuhi dalam pemodelan adalah minimum berjumlah 121 dan selanjutnya menggunakan perbandingan 5 observasi untuk setiap parameter.Karena itu bila kita mengembangkan model dengan 20 parameter, maka minimum sampel yang harus digunakan adalah sebanyak 100 sampel. Lebih lanjut Solimun (2002) menyatakan bahwa bila pendugaan parameter menggunakan metode kemungkinan maksimum (Maximum Likelihood); besar sampel yang disarankan adalah $=100-200$, dan minimum absolutnya $=50$. Sebanyak $5-10$ kali jumlah parameter yang ada di dalam model dan akan diduga sama dengan $5-10$ kali jumlah variabel manifes (indikator) dari keseluruhan variabel laten.

Dalam penelitian ini menggunakan sample size sebanyak 121, dengan demikian jumlah sampel yang digunakan dalam penelitian ini dapat dikatakan memenuhi ketentuan model persamaan struktural. 


\section{Uji Normalitas Data}

Uji normalitas bertujuan untuk menguji apakah data yang digunakan dalam penelitian memiliki distribusi normal baik secara multivariat maupun inivariat. Arbuckle (1997) dalam Ferdinand (2002:96) menyatakan bahwa jika nilai pada kolom c.r. (critical ratio) $\leq \pm 2,58$ pada taraf alpha sebesar $5 \%$, maka data dapat dikatakan bahwa tidak terdapat bukti distribusi data tersebut tidak normal.

Hasil uji normalitas data dengan menggunakan software AMOS Versi 16.00 sebagaimana tersaji pada Lampiran tidak ditemukan data yang tidak berdistribusi normal yang berarti distribusi data telah memenuhi kriteria normalitas data.

\section{Uji Outliers Data}

Pengujian outliers bertujuan untuk mengetahui kondisi observasi dari suatu data yang memiliki karakteristik unik dan nampak sangat jauh berbeda dengan observasi-observasi lainnya. Ottiers terjadi bila observasi muncul dengan nilai ekstrim yang disebabkan kesalahan prosedur, keadaan yang benar-benar khusus, hal tertentu yang tidak diketahui penyebabnya, atau akibat kombinasi.

Dalam penelitian ini uji outliers menggunakan kriteria Jarak Mahalanobis (Mahalanobis distance pada tingkat probabilitas lebih kecil dari $\alpha=0,05$ atau 95 $\%$ ). Jarak Mahalanobis dievaluasi dengan menggunakan $\chi^{2}$ pada derajat bebas sebesar jumlah variabel (observed variable) yang digunakan dalam penelitian itu. Jika nilai mahalanobis distance $>$ nilai $\chi^{2}$ maka terdapat outlier, begitu pula sebaliknya.

Jumlah indikator variabel dalam penelitian ini adalah 43 indikator variabel sehingga $\chi^{2}$ adalah $(43: 0.05)=59.300$ Data yang mempunyai nilai mahalanobis distance lebih besar dari $\chi^{2}$ menunjukkan terjadi multivariate outliers. Hasil output pengolahan data dengan menggunakan software AMOS tidak terdapat nilai mahalanobis distance lebih besar dari nilai $\chi^{2}=59.300$. Nilai mahalanobis distance maksimum adalah 36.228 pada observasi atau sampel ke 62 dan nilai mahalanobis distance minimum adalah 9.944 pada observasi atau sampel ke 114 .

Selanjutnya evaluasi outliers data secara univariat menurut Ferdinand (2002:103) mengemukakan bahwa untuk mendeteksi univariat outliers dapat dilakukan dengan menentukan nilai ambang batas yang akan dikategorikan sebagai outliers dengan cara mengkonversi data penelitian kedalam standard score (zscore) yang mempunyai nilai rata-rata nol dengan standar deviasi sebesar 1 . Lebih lanjut Hair, dkk (1995) dalam (Ferdinand 2002:98) mengemukakan bahwa untuk sampel besar (diatas 80 observasi), pedoman evaluasi adalah nilai ambang batas $z$ score berada pada rentang $3-4$, oleh karena itu observasi yang memiliki $z$-score $\geq$ 4,0 akan dikategorikan sebagai outliers.

\section{Hasil Pengujian Kesesuaian Model}

Berdasarkan cara penentuan nilai dalam model maka variabel pengujian model pertama ini dikelompokkan menjadi variabel eksogen dan variabel endogen. Variabel eksogen adalah variabel yang nilainya ditentukan diluar model, sedangkan variabel endogen adalah variabel yang nilainya ditentukan dari model hubungan yang dibentuk. Termasuk dalam kelompok variabel eksogen adalah 
kualitas layanan, sedangkan yang tergolong variabel endogen adalahkepercayaan, komitmen dan loyalitas. Model dikatakan baik bilamana pengembangan model hipotesis secara teoritis didukung oleh data empirik. Dalam penggunaan alat analisis SEM pengujian model dibenarkan untuk dilakukan modifikasi model dengan tujuan untuk memperoleh hasil sesuai dengan ketentuan-ketentuan yang dipersyaratkan berdasarkan Kriteria Goodness of Fit Indices Overall Model alat analisis SEM. Berdasarakan hasil pengujian model pada tahap awal syarat Kriteria Goodness of Fit Indices Overall Model telah memenuhi syarat sehingga tidak perlu dilakukan modifikasi model sebab telah terjadi kesesuaian data dengan model yang dibangun dalam penelitian ini. Hasil pengujian model yang dibangun dalam kerangka konseptual penelitian ini dapat dilihat pada gambar 2 berikut ini :

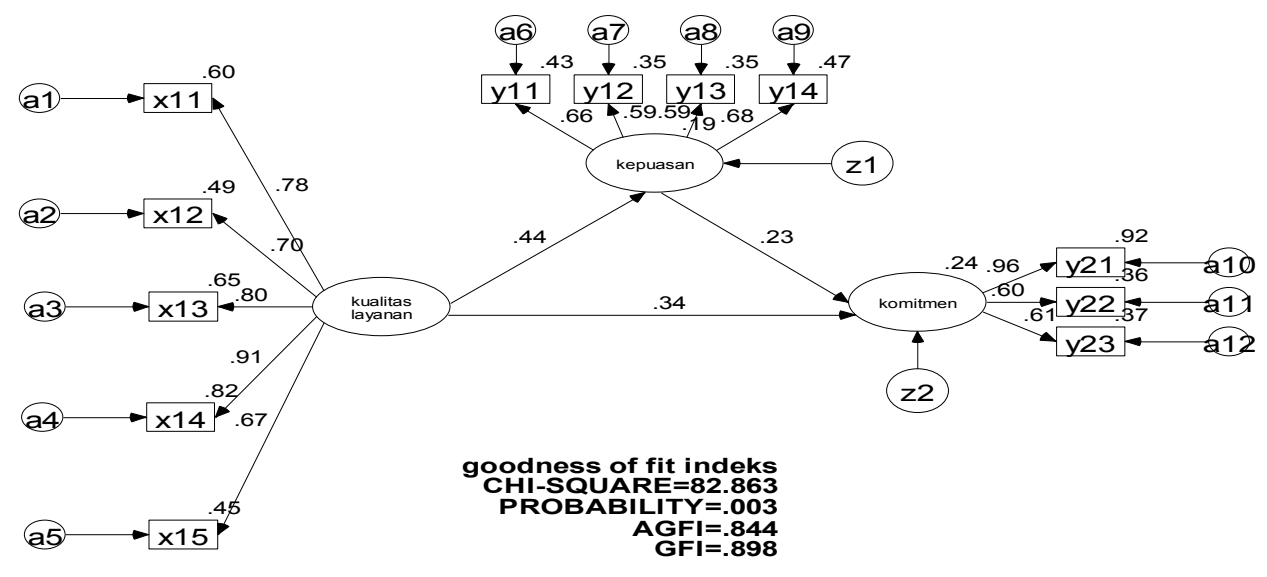

Gambar 2 : Uji Model Goodness of Fit

Setelah dilakukan pengujian ful model dengan nilai Chi-square, Probability, CFI, TLI, AGFI dan RMSEA dari model yang dibangun dapat memenuhi yang dipersyaratkan sesuai ketentuan Kriteria Goodness of Fit Indices Overall Model. selanjutnya model ini sudah dianggap sebagai hasil pengujian ful model tanpa perlu dimodifikasi. Hasil uji model (lampiran-7), dievaluasi berdasarkan Goodness Of Fit Indices pada Tabel 1 berikut dengan disajikan kriteria model serta nilai kritisnya yang memiliki kesesuaian data.

Tabel 1. Evaluasi Kriteria Goodness of Fit Indices Overall Full Model

\begin{tabular}{|c|c|c|c|}
\hline $\begin{array}{c}\text { Goodness of Fit } \\
\text { Index }\end{array}$ & Cut-of Value & $\begin{array}{c}\text { Hasil } \\
\text { Model }\end{array}$ & Keterangan \\
\hline Chi-square & Diharapkan kecil & 82.863 & Baik \\
\hline Probability & $\geq 0.05$ & 0.003 & Baik \\
\hline$G F I$ & $\geq 0.90$ & 0.844 & Marginal \\
\hline$A G F I$ & $\geq 0.90$ & 0.898 & Marginal \\
\hline
\end{tabular}

Sumber : Hair (1995), Arbuckle (1997) 
Dari evaluasi model yang diajukan menunjukkan bahwa evaluasi terhadap model konstruk secara keseluruhan ternyata dari berbagai kriteria sudah tidak terdapat pelanggaran kritis sehingga dapat dikemukakan bahwa model relatif dapat diterima atau sesuai dengan data sehingga dapat dilakukan uji kesesuaian model selanjutnya. Dari jalur yang diuji tidak terdapat indikator yang tidak signifikan yang terlihat dari nilai probabilitas atau $p$-nya diatas 0,05 (level 5\%) serta nilai $t_{\text {hitung }}$ diatas nilai $\mathrm{t}_{\text {tabel. }}$.

Analisis hubungan langsung (direct effect) antar konstruk dari model dapat dibandingkan untuk mengevaluasi hubungan setiap konstruk terhadap pengaruh langsung yang tidak lain adalah koefisien dari semua garis koefisien dengan anak panah satu ujung (Augusty,2005:55) yang hasil ujinya disajikan pada Tabel 2 berikut :

Tabel 2. Hasil Hipotesis Penelitian Direct Path.

\begin{tabular}{|l|c|c|c|c|}
\hline $\begin{array}{c}\text { Variabel } \\
\text { Independen }\end{array}$ & $\begin{array}{c}\text { Variabel } \\
\text { Dependen }\end{array}$ & $\begin{array}{c}\text { Efek Koef Path } \\
\text { Direct }\end{array}$ & (P Value) & Ket \\
\hline Kualitas layanan & Kepuasan & 0,438 & 0.000 & Sig \\
\hline Kualitas layanan & Komitmen & 0,342 & 0.002 & Sig \\
\hline Kepuasan & Komitmen & 0.226 & 0.009 & Sig \\
\hline
\end{tabular}

Sumber : Data diolah

Berdasarkan hasil pengujian full model dapat diketahui terdapat jalur hipotesis yang terdukung data empiris dan diterima adalah:

H 1: Kualitas layanan memiliki pengaruh positif dan signifikan terhadap kepuasan nasabah pada BPD Sultra Cabang Utama.

H 2 : Kualitas layanan memiliki pengaruh positif dan signifikan terhadap komitmen nasabah pada BPD Sultra Cabang Utama.

H 3 : Kepuasan nasabah memiliki pengaruh positif dan signifikan terhadap komitmen pada BPD Sultra Cabang Utama.

\section{Hasil Pengujian Hipotesis}

Pengujian hipotesis dalam penelitian ini bertujuan untuk menjawab apakah hipotesis yang diajukan dalam penelitian ini diterima atau ditolak. Taraf signifikan estimasi parameter yang diterapkan dalam penelitian ini sebesar $95 \%$ atau $\alpha=0,05$. Uji hipotesis dalam penelitian ini dilakukan persis sama dengan uji hipotesis regresi umumnya, yaitu dengan uji signifikansi pada probability $(\mathrm{p}) \alpha \leq 0,05$. Atau uji Critical Ration $(\mathrm{CR})>2$ digunakan untuk melihat signifikansi koefisien regresi yang dihasilkan oleh berbagai hubungan kausal dalam model.

Dasar pengambilan keputusannya adalah :

1. Apabila $\mathrm{p}<\alpha=0,05$, maka Ho ditolak, Ha diterima artinya terdapat pengaruh signifikan antara variabel eksogen terhadap variabel endogen.

2. Apabila $\mathrm{p}>\alpha=0,05$, maka Ho diterima, Ha ditolak artinya tidak terdapat pengaruh signifikan antara variabel eksogen terhadap variabel endogen. 


\section{Pengaruh Kualitas Layanan (X) terhadap Kepuasan ( $\left.\mathbf{Y}_{1}\right)$}

Berdasarkan hasil pengolahan data yang disajikan pada Tabel 2 menunjukkan bahwa pengaruh kualitas layanan terhadap kepercayaan diperoleh nilai koefisien jalur sebesar 0,438 dengan nilai probalitas 0,000 yang berarti $\mathrm{p}<\alpha=0,05$ artinya variabel kualitas layanan mempunyai pengaruh positif dan signifikan terhadap variabel kepuasan nasabah pada BPD Sultra Cabang Utama dengan kontribusi efek variabel kualitas layanan terhadap kepuasan nasabah sebesar 0,438 mempunyai makna bahwa 43,2\% terjadi kecenderungan meningkatnya kepuasan nasabah pada BPD Sultra Cabang Utama disebabkan oleh variabel kualitas layanan. Hal ini menunjukkan bahwa hipotesis 1 (satu) yang menyatakan kualitas layanan memberikan pengaruh yang positif dan signifikan terhadap kepuasan nasabah dapat diterima.

\section{Pengaruh Kualitas Layanan $(X)$ terhadap Komitmen $\left(Y_{2}\right)$}

Berdasarkan hasil pengolahan data yang disajikan pada Tabel 2 menunjukkan bahwa pengaruh kualitas layanan terhadap komitmen diperoleh nilai koefisien jalur sebesar 0,342 dengan nilai probalitas 0,002 yang berartip $<\alpha=0,05$ artinya variabel kualitas layanan juga mempunyai pengaruh positif dan signifikan terhadap variabel komitmen nasabah pada BPD Sultra Cabang Utama dengan kontribusi efek variabel kualitas layanan terhadap komitmensebesar 0,342, mempunyai makna bahwa 34,2\% terjadi kecenderungan meningkatnya komitmen nasabah pada BPD Sultra Cabang Utama disebabkan oleh variabel kualitas layanan. Hal ini menunjukkan bahwa hipotesis 2 (dua) yang menyatakan kualitas layanan memberikan pengaruh yang positif dan signifikan terhadap komitmen dapat diterima.

\section{Pengaruh Kepuasan $\left(Y_{1}\right)$ terhadap Komitmen $\left(\mathbf{Y}_{2}\right)$}

Berdasarkan hasil pengolahan data yang disajikan pada Tabel 2 menunjukkan bahwa pengaruh kepuasan nasabah terhadap komitmen diperoleh nilai koefisien jalur sebesar 0,226 dengan nilai probabilitas 0,009 yang berarti $\mathrm{p}<\alpha=0,05$ artinya variabel kepuasan juga mempunyai pengaruh positif dan signifikan terhadap variabel komitmen nasabah pada BPD Sultra Cabang Utama dengan kontribusi efek variabel kepuasan terhadap komitmen nasabah sebesar 0,226 mempunyai makna bahwa $22,6 \%$ terjadi kecenderungan meningkatnya komitmen nasabah pada BPD Sultra Cabang Utama karena meningkatnya kepuasan nasabah. Hal ini menunjukkan bahwa hipotesis 3 (tiga) yang menyatakan kepuasan nasabah memberikan pengaruh yang positif dan signifikan terhadap komitmen nasabah dapat diterima.

\section{KESIMPULAN}

\section{Kesimpulan}

1. Kualitas layanan mempunyai pengaruh yang positif dan signifikan terhadap kepuasan nasabah artinya bahwa semakin bagus pelayanan yang diberikan maka semakin besar kepuasan nasabah terhadap bank BPD. Perubahan peningkatan indikator kualitas layanan akan meningkatkan 
kepuasan nasabah terhadap BPD Sultra Cabang Utama.

2. Kualitas layanan mempunyai pengaruh yang positif dan signifikan terhadap komitmen nasabah artinya bahwa semakin bagus pelayanan yang diberikan maka nasabah semakin berkomitmen menjalin hubungan kerjasama dengan bank. Perubahan peningkatan indikator kualitas layanan akan meningkatkan komitmen nasabah terhadap BPD Sultra Cabang Utama

3. Kepuasan nasabah mempunyai pengaruh yang positif dan signifikan terhadap komitmen nasabah artinya bahwa semakin puas nasabah terhadap layanan yang diberikan bank maka semakin besar komitmen nasabah terhadap bank BPD. Perubahan peningkatan indikator kepuasan akan meningkatkan komitmen nasabah terhadap BPD Sultra Cabang Utama.

\section{Saran-Saran}

1. Bagi Manajemen BDP Sultra adalah Komitmen nasabah perlu lebih ditingkatkan dengan pendekatan keakraban, baik secara kekerabatan maupun personal. Karyawan BPD Sultra yang sebagian besar merupakan penduduk asli/orang lokal daerah setempat, merupakan faktor penunjang yang penting dalam menjalin komunikasi yang efektif sehingga hubungan kemitraan nasabah dengan bank dapat berjalan baik dan bertahan lama dan Pemberian pelatihan/training untuk meningkatkan kualitas layanan tidak terbatas hanya pada petugas bagian customer service dan teller saja, melainkan hendaknya melibatkan pula petugas satpam dan cleaning service. Sehingga peningkatan pelayanan dapat terjadi disemua lini. Pelayanan yang baik dimata nasabah, akan meningkatkan nilai positif bank sehingga nasabah cenderung merekomendasikannya pada pihak lain.

2. Bagi Peneliti mendatang : (1).Jika menggunakan variabel yang sama dengan penelitian ini disarankan agar mengkaji pengaruh langsung antara variabel kualitas layanan terhadap relationship intention nasabah sekaligus mengkaji hubungan secara tidak langsung variabel kualitas layanan terhadap relationship intention melalui variabel kepuasan dan komitmen nasabah. (2) Memperluas obyek penelitian pada seluruh nasabah pengguna layanan, bukan hanya nasabah tabungan, sehingga gambaran tingkat kualitas layanan diperoleh secara menyeluruh terhadap semua bagian layanan yang ada di bank.

\section{DAFTAR PUSTAKA}

Adamson, Ivana, Kok Mun Chan and Donna Handford, 2003, Relationship Marketing Customer commitment and Trust as a strategy for the smaller Hong Kong Corporate Banking sector, International Of Journal of Banking marketing 21 (6) 347-348

Agung, Ken Hermanto, 2006, Analisis pengaruh Kualitas Layanan, Komitmen dan Kepercayaan terhadap Loyalitas Konsumen (Studi Kasus Pada Nasabah 
Tabungan Simpeda Bank Jateng), Tesis, Universitas Diponegoro, Semarang

Alma, Buchari, 2004, Manajemen Pemasaran dan Pemasarn Jasa, Alfabeta, Cetakan Keenam, Jakarta

Anderson, Erin and Barton Weitz, 1992, "The Use of Pledges to Build and Sustain Commitment in Distribution Channels, Journal of Marketing Research, Vol.XXIX, Februari, p.18-34

Arifianto, Nito Prabowo, 2007, Analisis Faktor-Faktor Yang Mempengaruhi Kepuasan Layanan (Studi Kasus di PT.Bank OCBC NISP Cabang Pemuda Surabaya), Tesis, MagisterManajemen Teknologi, Institut Teknologi Sepuluh Nopember, Surabaya

Arikunto, Suharsimi, 2000, Manajemen Penelitian, PT.Rhineka Cipta, Jakarta

Barness, James G. 2001, Secret Of Customer Relationship Management, Terjemahan Andreas Winardi, 2003, Yogyakarta, Penerbit Andi Jogyakarta

Bitner, Mary Jo, 1995, Building Service Relationship : Its All About Promise, Journal of The Academy of Marketing Science, Vol.23.No.4.pp.246-251

Boonajsevee, Bhoomipan,2005, Relationship Marketing : Loyalty Intentions in New Era of Thai Bank Marketing, Disertation, The Wayne Huizenga Graduate School of Business and Enterpreneurship, Nova Southeastern University

Chan, Syaifuddin,2003, Relationship Marketing : Inovasi Pemasaran Yang membuat Pelanggan Bertekuk Lutut, PT Gramedia Pustaka Utama, Jakarta

Cronin, Joseph.J, and Steven A, 1992, Measuring Service Quality : A Reexamination and Extention, Journal of Marketing 56, Juli :55-68

Crosby, Lawrence, Evans, Kenneth \& Cowles, Deborah. 1990. Relationships quality inservices selling: an interpersonal influence perspective. Journal of Marketing, 54 (July), 68-81

Darsono, Licen I, 2010, Hubungan Perceived Service Quality dan Loyalitas : Peran Trust dan Satisfaction sebagai mediator, Jurnal Bisnis Perspektif Vol.2,1, 43-57

Donnely, Patricia.M and Joseph P. Cannon, 1997, An Examination of The Nature of Trust in Buyer-Saller Relationship, Journal Marketing, April No.6.pp.31-35 
246 MODERNISASI, Volume 9, Nomor 3, Oktober 2013

Ferdinand Augusty, 2006, Structural Equation Modeling, Dalam Penelitian Manajemen, Aplikasi Model-Model Rumit Dalam Penelitian Untuk Tesis Magister Dan Disertasi Doktor, Semarang, BP UNDIP.

Foster B.D and Cadogan Josep.W, 2000, Relationship Selling and Customer Loyalty : An Empirical Investigation, Marketing Inteligence \& Planing, Vol.18.No.44.pp.185-199

Fullerton, Gordon \& Shirley Taylor, 2000, The Role of Commitment in Service Relationship, Kingston, Ontario : Scholl of Business Acadia University, Limited Publication.p.3-18

Ghozali, Imam, Fuad, 2008, Struktural Equation Modeling, Teori,konsep dan aplikasi, Badan Penerbit Universitas Diponegoro

Hair, Joseph F, Rolph E Anderson, Ronald L Tatham, and William C Black 1998, Multivariate Data Analysis. New Jersey Prentise Hall : New Jersey : Prentice - Hall

Handayani, Sri, 2008, Pengaruh Kepercayaan Dan Komitmen Terhadap Loyalitas Nasabah Pada PT.Bank Negara Indonesia (Persero) Tbk. Cabang Padang, Tesis, Universitas Andalas, Padang

Hasibuan, S.P, Malayu, 2005, Dasar-Dasar Perbankan, Penerbit Bumi Aksara, Jakarta

Henning-Thurau Thorsten, Kevin P. Gwinner, Dwayne D.Gremier, 2002, Understanding Relationship Marketing Outcome : An Integration of Relation Benefits and Relationship Quality, Journal of Service Researc, Vol.4.No.3.pp.230-247

Husein, Umar, 2005, Riset Pemasaran dan Perilaku Konsumen, PT.Gramedia Pustaka Utama bekerjasama dengan Jakarta Business Research Center (JBRC), Jakarta

Indarto, Agus, 2006, Pengaruh Factor-Faktor Pembentuk Komitmen Keterhubungan Nasabah Pada Sektor Perbankan, Tesis, Universitas Gajahmada, Yogyakarta

Imam, Sentot, 2010, Manajemen Pemasaran Bank, Penerbit Graha Ilmu

Jasfar, Farida, 2002, Kualitas Jasa dan Hubungannya dengan Loyalitas serta Komitmen Konsumen : Studi Pada Pelanggan Salon Kecantikan, Jurnal Siasat Bisnis, No.7, Vol.1, Hal 43-64 
2005, Pentingnya Kualitas Pelayanan Dalam membangun Kepercayaan Pelanggan dan Keputusan Membeli, Jurnal Manajemen dan Pemasaran, Vol.1, No.1, Maret 2005

Jill, Griffin, 2003, Customer Loyalty : Menumbuhkan \& Mempertahankan Kesetiaan Pelanggan, Edisi Revisi dan Terbaru Bahasa Indonesia, Penerbit Erlangga, Jakarta

Kotler, Phillip, 2000, Marketing Management, Edition Milenium, Nortwestern University

Lamb,Jr., Charles W, et all, 2001, Pemasaran, Terjemahan, Buku 1, Salemba Empat, Jakarta

Morgan, Robert.M, \& Shelby D. Hunt, 1994, The Commitment - Trust Theory of Relationship Marketing, Journal of Marketing, Juli, No.58.pp.20-38

Moorman, Christine, Gerald Zaltman, and Rohid Despande, 1992, Relationship Between Providers and Users of Market Research : The Dinamics of Trust Within and Between Organizations, journal of Marketing Research, Agustus, p.314-318

Mukherjee, Avinanda, and Prithwiraj Nath, 2003, A Model of trust in Online Relationship Banking, Internasional Journal of Bank Marketing 21 (1) : 55-15

Ndubisi, Nelson Oly, 2005, Relationship Marketing And Customer Loyalty, Marketing Intelligence \& Planning Vol. 25 No. 1, 2007 pp. 98-106

Oliver, Richard L, 1997 Satisfaction : A Behavioral Perspective on the consumer New York: Irwin / Mc- Graw Hill.

Parasuraman, A., Valerie A. Zeithaml, and Leonard L. Berry, 1988, SERVQUAL : A Multiple-Item Scale for Measuring Consumer Perception of Service Quality, Journal of Retailing 64 (1) : 12-35

Parawansa, Dian Anggraece Sigit, 2012, The Mediating Effect of Trust, Satisfaction, and Commitment On The Relationshiop Between Service Quality And Customer Loyalty in Islamic Banking of Indonesia, Universitas Hasanuddin, Makassar

Rangkuti, Freddy, 2006, Measuring Customer Satisfaction, PT.Gramedia Pustaka Utama, Jakarta

Ratih, Meithia Puspa, 2009, Analisis Kepuasan dan Loyalitas Terhadap Kualitas Pelayanan bank XYZ cabang Pondok Indah Jakarta, Tesis, Pascasarjana Manajemen Bisnis, Institut Pertanian Bogor 
Reischeld, F.F., \& sasser, W.E.Jr., 1990, Zero Deffections : Quality Comes to Service, Harvard Business Review, September-Oktober, pp.105-11

Sentana, Aso, 2006, Excelent Service \& Customer Satisfaction, Penerbit PT Elex Media Komputindo, Kelompok Gramedia

Sidik, Moh, 2009, Metodologi Penelitian dan Bisnis, PT Graha Ilmu

Singh, Jagdip, and Deepak Sirdeshmukh, 2000, Agency and Trust Mechanism in Consumer Loyalty in Realtional Exchanges, Journal of Marketing 66, Januari : $15-47$

Simamora, Bilson, 2003, Memenangkan Pasar, PT Gramedia Pustaka Utama, Jakarta

Sugiyono, 2009, Metode Penelitian Bisnis, Penerbit Alfabeta, Bandung

Sugiarto, Endar, 1999, Psikologi Pelayanan Dalam Industri Jasa, Penerbit PT.Gramedia Pustaka Utama, Jakarta

Sulistiarini, Endang, 2007, Pengaruh economic conten, resource content dan sosial content terhadap kepuasan, kepercayaan dan komitmen serta relationship intention Bank Sumatra Utara, Universitas Airlangga, Surabaya

Tjiptono, Fandy, 1996, Manajemen Jasa, Cetakan Pertama, Penerbit Andi, Yogyakarta

------------, 2005, Pemasaran Jasa, Malang, Jawa Timur-Indonesia, Penerbit Bayumedia Publishing

Yusuf, Hayat, 2007, Pengaruh Kualitas Layanan Terhadap Kepuasan Pelanggan, Citra Perusahaan dan Loyalitas Pelanggan Pada perusahaan Jasa Penerbangan di Sulawesi Selatan, Disertasi, Pascasarjana Universitas Brawijaya, Malang.

Usmara, A., dan Budianingsih B , 2003. Marketing Classics. Jogyakarta Penerbit Amara Books

Waluyo, Purwanto, 2004, Analisis Strategi Kualitas Pelayanan dan Kinerja bankBank BPR di Jawa Tengah, Disertasi

Zeithmal. Valerie A and Mary Jo Bitner, 2000, Service Marketing : Integrating Customer Focus Across the Firm Boston : Macgraw Hill Companies 